MaPan : Jurnal Matematika dan Pembelajaran

p-ISSN: 2354-6883 ; e-ISSN: 2581-172X

Volume 8, No 1, June 2020 (153-167)

DOI: https://doi.org/10.24252/mapan.2018v8n1a12

\title{
THE DEVELOPMENT OF SCIENCE, TECHNOLOGY, ENGINEERING, AND MATHEMATICS (STEM)-BASED MATHEMATICS TEACHING MATERIALS TO INCREASE MATHEMATICAL CONNECTION ABILITY
}

\author{
M. A. Niam1), M. Asikin') \\ 1,2Universitas Negeri Semarang \\ 1,2Kampus Sekaran, Gunungpati, Semarang \\ E-mail:m.a.29niam@gmail.com²), asikin.mat@mail.unnes.ac.id ${ }^{2)}$
}

Received June 08, 2020; Revised June 29, 2020; Accepted June 29, 2020

\begin{abstract}
:
This research is development research that aims to develop mathematics teaching materials related to Science, Technology, Engineering, and Mathematics (STEM). This research uses the stages of Research and Development, including problem and data collection, product design, design validation, product test (practicality test), trial test (pretest and posttest), and final product. The results show that teaching materials are valid, practical, and effective to increase mathematical connection ability. The results of the test indicate that teaching materials are valid to use in learning with a percentage of $94.42 \%$. The practicality test results show that teaching materials are easily practised by students, with a percentage of $87.47 \%$. The analysis of the results of the pretest and posttest showed that there was an effective increase in the mathematical connection ability with the n-gain test results of 0.628 on the medium criteria. Thus, mathematics teaching materials in this research can be used in learning, and the copyright was submitted by the electronic intellectual wealth General Directory.
\end{abstract}

Keyword: Development, Teaching Materials, STEM, Mathematical Connection

\section{PENGEMBANGAN BAHAN AJAR MATEMATIKA BERBASIS SCIENCE, TECHNOLOGY, ENGINEERING, AND MATHEMATICS (STEM) UNTUK MENINGKATKAN KEMAMPUAN KONEKSI MATEMATIS}

\begin{abstract}
:
Penelitian ini merupakan penelitian pengembangan yang bertujuan untuk mengembangkan bahan ajar matematika yang berhubungan dengan Science, Technology, Engineering, and Mathematics (STEM). Penelitian ini menggunakan tahapan penelitian dan pengembangan, yaitu masalah dan pengumpulan data, desain produk, validasi desain, uji produk (tes kepraktisan), uji coba (pretest dan posttest), dan produk akhir. Hasil penelitian menunjukkan bahwa bahan ajar tersebut valid, praktis, dan efektif untuk meningkatkan kemampuan koneksi matematis. Hasil tes menunjukkan bahwa bahan ajar valid untuk digunakan dalam pembelajaran dengan persentase $94,42 \%$. Hasil tes kepraktisan menunjukkan bahwa bahan ajar mudah digunakan oleh siswa, dengan persentase $87,47 \%$. Analisis hasil pretest dan posttest menunjukkan bahwa ada peningkatan yang efektif dalam kemampuan koneksi matematis dengan hasil tes n-gain dari 0,628 pada kriteria medium. Dengan demikian,
\end{abstract}


materi pengajaran matematika dalam penelitian ini dapat digunakan dalam pembelajaran, dan hak cipta disampaikan oleh kekayaan intelektual elektronik direktori umum.

Kata kunci: Pengembangan, Bahan Ajar, STEM, Koneksi Matematis

How to Cite: Niam, M, A., \& Asikin, M. (2020). The Development of Science, Technology, Engineering, and Mathematics (STEM)-Based Mathematics Teaching Materials to Increase Mathematical Connection Ability. MaPan: Jurnal Matematika dan Pembelajaran, 8(1), 153-167. https://doi.org/10.24252/mapan.2018v6n1a12.

\section{INTRODUCTION}

7 ducation is the main thing that must be owned by the community as a milestone in practicing heterogeneous and modern life. In Law Number 20 of 2003, education is a conscious and planned effort to create a learning atmosphere and learning process so that students actively develop their potential to have religious-spiritual strength, self-control, personality, intelligence, noble character, and skills needed by himself, society, nation, and country. One of the real efforts that can be done to improve national education standards is the use of learning sources. Teaching material is one of the learning sources that apply various concepts according to the needs of the standard competencies and basic competencies mentioned in the curriculum (Rokhman \& Yuliati, 2010).

Mathematics is one branch of science that has an important role in the development of science in this globalization era. The development of science and knowledge requires good mathematical abilities (Setiawan, Suyitno, \& Susilo, 2017). The purpose of learning mathematics is that students must have five mathematical ability standards, namely problem-solving, communication, connection, reasoning, and representation (NCTM, 2000). In mathematics learning, understanding is needed in harmony with the trends that exist in the current era of globalization, one of which is learning by using the STEM approach.

STEM is an acronym for science, technology, engineering, and mathematics (Pimthong \& Williams, 2020). The STEM approach uses two or more subjects in the STEM coverage area and also uses one or more other subjects in school (Sanders, 2009). The subjects of science, technology, engineering, and mathematics are closely related to each other (Tseng, Chang, Lou, \& Chen, 2013). The development of STEM-based mathematics teaching 
materials will have a positive influence on students for material association with other aspects and concepts mastery in learning. This is supported by research which states that learning using STEM-based teaching materials can improve students' concept mastery (Pangesti, Yulianti, \& Sugianto, 2017). It is necessary to develop STEM-based mathematics teaching materials that can increase students' mathematical connection ability.

The mathematical connection is students' understanding in connecting mathematical ideas that facilitate the formulation ability and verify deductive conjectures between topics (Rohendi \& Dulpaja, 2013). The purpose of mathematical learning is students can understand mathematical concepts, explain interrelationships between concepts, and apply concepts or algorithms flexibly, accurately, efficiently, and precisely in problem-solving (Astuti, Hartono, Bunayati, \& Sriwijaya, 2017). In order to broaden students' insights, mathematical problems need to be connected with other materials, also connected with examples of daily life or applied to the field of technology, which is all expected to be based on conservation (Pujiastuti, Mulyono, \& Soedjoko, 2018).

The results showed that the ability of mathematical connections between one topic with another topic was around $55 \%$, while the ability of mathematical connections with other sciences was $40 \%$, and the lowest mathematical connection ability was connections with real-life which was only $2 \%$ (Saminanto \& Kartono, 2015). So, it can be concluded that the mathematical connection ability of students is still relatively low. Some learning resources that have not been able to train students' thinking ability can be a trigger factor for the low ability of mathematical connections among students. STEM-based mathematics teaching materials can be the right choice because learning using these teaching materials focuses on learning students to try to find solutions to problems that have many solutions (Phungsuk, Viriyavejakul, \& Ratanaolarn, 2017).

Based on the above background description, further research is needed on "the development of STEM-based mathematics teaching materials to increase the ability of Mathematical Connections". The purpose of this study is to determine the level of validity and the level of practice of the STEM-based mathematics teaching material that is developed and to know the increase in the ability of mathematical connections after the application of the STEM-based mathematics teaching material. 


\section{RESEARCH METHOD}

This research uses the Research and Development (R\&D) method. R\&D method is a research method used to produce specific products and test the effectiveness of these products (Sugiyono, 2017). Through this research method, a product in the form of STEM mathematics teaching materials is developed to increase mathematical connection ability.

In this research, the teaching materials is a book for students. The implementation of this study began with the design of validated teaching materials to 7 validators from december 2019 until february 2020 to validate the validity of STEM-based mathematics teaching materials on two variables linear equation system. Then, it was continued with the practical test that is carried out in the gap text, which must be completed by students in the allotted time. Next, working on pretest and posttest with 6 questions derived from teaching materials related to the indicator of mathematical connection ability to find out the increase of mathematical connection ability, which was carried out on 2-16 march 2020 at MTs Nahdlatusy Syubban Demak.

The development research procedure used in this study is a modification of the R\&D method (Sugiyono, 2017). The stages in this study include problems and data collection, product design, design validation, product test (practical test), trial test (pretest and posttest), and final product. Data collection techniques are used to obtain research data included a questionnaire of the level of validity of STEM-based mathematics teaching materials and tests on the practice of teaching materials and students' mathematical connection ability. The results of the validity level and practical level are analyzed using the following equation.

$$
p=\frac{f}{n} \times 100 \%(\text { Sudijono, 2014) }
$$

Where $p$ is the percentage score, $f$ is the number of scores obtained, and $n$ is the maximum number of points scored. Furthermore, the results of the analysis of each test are associated with assessment criteria. Criteria for the level of validity of teaching materials are shown in table 1 (Akbar, 2013). 
Table 1. Criteria for the Level of Validity

\begin{tabular}{cc}
\hline Percentage Score & Criteria \\
\hline $\mathbf{1} \%<$ score $\leq \mathbf{5 0} \%$ & Not valid \\
$\mathbf{5 0} \%<$ score $\leq \mathbf{7 0} \%$ & Rather \\
$\mathbf{7 0} \%<$ score $\leq \mathbf{8 5} \%$ & Valid \\
$\mathbf{8 5} \%<$ score $\leq \mathbf{1 0 0} \%$ & Excellent \\
\hline
\end{tabular}

The criteria of practicality level of teaching materials, according to Rankin \& Culhane (Rosmiani, 2009), is shown in table 2.

Table 2. Criteria for the Level of Practicality

\begin{tabular}{cc}
\hline Readibility Levels & Criteria \\
\hline $\mathbf{1} \%<$ score $\leq \mathbf{4 0} \%$ & Difficult for students \\
$\mathbf{4 0} \%<$ score $\leq \mathbf{6 0} \%$ & Suitable for students \\
$\mathbf{6 0} \%<$ score $\leq \mathbf{1 0 0} \%$ & easy to understand \\
\hline
\end{tabular}

The increasing score in mathematical connection ability can be analyzed using the gain scores (Hake, 1999), the formula that is used is:

$$
\text { normalized Gain }(g)=\frac{\text { postest score }- \text { pretest score }}{\text { maximum score }- \text { pretest score }}
$$

Criteria on the analysis of gain to be used, is shown in table 3 (Hake, 1999).

\begin{tabular}{cc} 
Table 3. The Criteria of & N-Gain $(\mathrm{g})$ \\
\hline $\mathbf{N}$-Gain & Criteria \\
\hline$(\boldsymbol{g}) \leq \mathbf{0 , 3 0}$ & Low \\
$\mathbf{0 , 3 0}<(\boldsymbol{g}) \leq \mathbf{0 , 7 0}$ & Medium \\
$\mathbf{0 , 7 0}<(\boldsymbol{g})$ & High \\
\hline
\end{tabular}

\section{RESULTS AND DISCUSSION}

\section{Problems and Data Collection}

In the first, researchers conducted observations at the MTs Nahdlatusy Syubban Demak. Observations were made to the Mathematics teacher of MTs Nahdlatusy Syubban Demak. The teacher stated that learning mathematics in class so far had used teaching materials in the form of Student Worksheets, which contained a material summary and practical formulas to answer the problem. The teaching material is not equipped with problems that can connect 
the student's ability with other aspects such as science, technology, and engineering. Students are encouraged to memorize these practical formulas in preparation for tests. It accord with student worksheets that is material in learning that guides students on how to learn with practical learning steps (Kolomuc, Ozmen, Metin, \& Acisli, 2012).

STEM, which focuses on science and mathematics and combines these two disciplines with technology and engineering, has been defined in various ways (Acar, Tertemiz, \& Tasdemir, 2018). STEM in learning has better achievement than conventional learning (Lou, Shih, Diez, \& Tseng, 2011). It can be concluded that STEM-based teaching materials can improve students' concept mastery, characterized by an increase in the value of pretest to posttest (Pangesti, Yulianti, \& Sugianto, 2017). This problem underlies the development of STEM-based mathematics teaching materials in the Two-Variable Linear Equation System material as appropriate teaching materials and according to the needs of students.

The researcher analyzes the needs of teaching materials, which include analyses of core competencies, basic competencies, and competencies achievement indicators. Then, researchers compile a concept map to determine the order of material and make it easier for students to understand teaching materials correctly. It accord with the concept map that is proposed as tools for teaching, learning, and evaluating in obtaining structured knowledge to diagnoses misconceptions (Chiou, Lee, \& Liu, 2012).

\section{Product Design}

The researcher compiles drafts and layouts to produce a STEM-based teaching material product in terms of content and appearance. Students were engaged in both abstract learning (science and mathematics) and concrete application (Engineering and Technology) to increase learning capacity to absorb new material creatively and innovatively (John, Bettye, Ezra \& Robert, 2016). Teaching material contains Two-Variable Linear Equation System, which is related to the STEM aspects and assessment of teaching materials by BSNP.

The STEM-based mathematics teaching material consists of a discussion of the material in each section of teaching material that is given a picture according to the problem given. Using words and pictures in a media can have a better effect (Cloonan \& Fingeret, 2020). Teaching material consists of three main parts, namely beginning, content, and closing. figure 1 below is the instruction design of the use of STEM-based mathematics teaching material. 

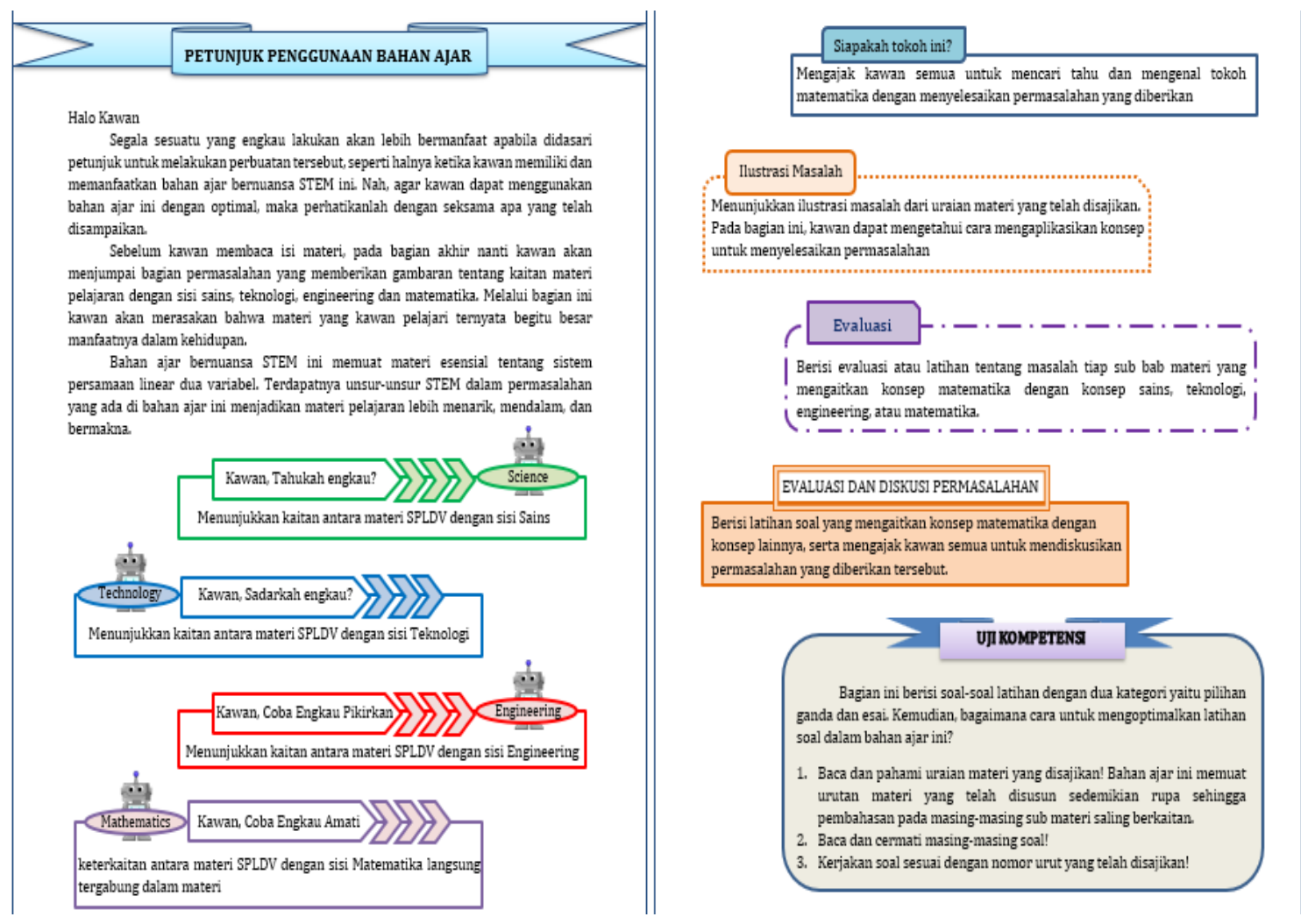

Figure 1. Instructional Design of the Use of Teaching Material

Teaching material begins with initial instructions that explain the relationship of the material with STEM aspects. Connection aspects of science are presented in a green container labeled "Science", the technological aspect is presented in a blue container labeled "Technology", the engineering aspect is presented in a red container labeled "Engineering", and the mathematics aspect is integrated with a purple container labeled "Mathematics". Before learning, students are given a problem to find out one of the mathematical figures contained in the container labeled "who is this character?". Problem illustration from the description of material contained in the container labeled "illustration of the problem". Evaluation of each sub-chapter that connect mathematical concepts to STEM aspects is contained in a container labeled "evaluation". The question exercises that connect mathematical concepts with other concepts, and invite discussion of a problem are contained in a container labeled "evaluation and discussion of problems". The final part of the teaching material labeled "competency test" as the final exercise in learning. It accord with research that explains learning that emphasizes the activeness of students to explore a 
concept or principle in mathematics through inquiry activities that can improve mathematical connection ability (Badjeber \& Fatimah, 2015).

\section{Design Validation}

The validity of Mathematics Teaching Materials

Assessment from teaching material consists of 3 aspects, namely aspects of validity content, presentation, and language. Based on the results of the validity test with STEM-based teaching materials, it is known the percentage of the validity of each aspect in teaching materials, as presented in table 4 .

Table 4. Result of Validity of Each Aspect in Teaching Material

\begin{tabular}{ccl}
\hline Aspect & $\mathbf{P ~ ( \% )}$ & Criteria \\
\hline Conten validity & 93,36 & Excellent \\
Presentation validity & 93,82 & Excellent \\
Language validity & 90,1 & Excellent \\
Average & 92,42 & Excellent \\
\hline
\end{tabular}

Teaching material contains aspects of content, presentation, and language by excellent criteria. Thus, teaching materials have achieved the validity based on aspects and assessment criteria of BSNP that have been modified. Therefore, teaching materials are valid to be produced and used in learning but need to be revised according to the validator's advice. The study states that the mathematics books with STEM approach that is compiled based on basic competencies contained in the 2013 curriculum are valid to use in learning after the validation process (Utami, Jatmiko, \& Suherman, 2018).

The assessment of content validity aspect shows that teaching material contains excellent criteria. Therefore, teaching materials will help students in mastering concepts and materials according to competencies that must be possessed (Nurichah, 2012). Evaluation of presentation validity aspect shows that teaching material contains excellent criteria because the presentation is coherent and consistent in 3 main parts, namely beginning, content, and closing according to BSNP criteria. Results of development teaching materials that refer to BSNP are declared to be excellent and effectively used in the learning process (Arafah, Ridlo, \& Priyono, 2012). Assessment of language aspects shows that teaching material contains excellent criteria. It accord with research that explains using language in teaching materials according to the rules of the Indonesian language, choice of words that are easy to understand, and using 
simple sentences will make it easier for students to understand the intent of the author (Nugraha \& Binadja, 2013).

\section{Product Test}

Practicality of Mathematics Teaching Material

A practical test was conducted on 23 students. A practical test is carried out in the gap text, which must be completed by students in the allotted time. The composition of gap text is based on the quoted text in teaching material, which is made in several 50 gap words. It accord with vocabulary and grammar that need to be conveyed in context and students must be given the opportunity to use the language they learn in class (Arikan, 2014).

The practicality test results of teaching materials get an average percentage value of $87.47 \%$. Students can answer test questions with an average total of about 43 correct answers. These results indicate that teaching materials are practical and easily understood by students according to the scale of practicability. Through practicality, it can be measured at a glance there is reading interest to students towards 2 things that contradict each other (Dobres, Chahine, \& Reimer, 2017). Thus, STEM-based mathematics teaching materials are practical and can be understood by readers well.

\section{Trial Test}

The trial test includes a pretest, delivery of core material from STEMbased teaching materials, and ends with a posttest. The pretest is used to evaluate the initial knowledge of students, while the posttest is used to measure the effectiveness of an experiment using teaching materials in learning (Chiou, Lee, \& Liu, 2012). Pretest and posttest aimed to determine the use of teaching materials can increase students' mathematical connection ability. Pretest and posttest results show that learning using teaching materials can increase students' scientific reasoning ability (Tsai, Jou, Wang, \& Huang, 2017). Therefore, it is necessary to conduct research to determine whether pretest and posttest are effective to increase mathematical connection ability.

Increased Mathematical Connection ability Prerequisite Test

The prerequisite test is normality tests from pretest and posttest data to find out whether data is normally distributed or not. The hypothesis proposed that is

$H_{0}$ : pretest and posttest data are normally distributed.

$H_{1}$ : pretest and posttest data are not normally distributed. 
The normality test in this study uses the Kolmogorov-Smirnov test with the help of the SPSS 24.0 program. Pretest and posttest data are said normally distributed if the value of $\operatorname{sig}>\alpha=0,05$. Based on the normality test results obtained significance value for pretest data is sig $=0,2>\alpha=0,05$ and postest is sig $=0,2>\alpha=0,05$. Based on testing criteria, $H_{0}$ is accepted. This shows that the pretest and posttest data from students are normally distributed. Then pretest and posttest data can be analyzed with the next test in the form of an ngain test.

N-Gain Test

Improvement of students 'mathematical connection ability is assessed through written tests with six questions from STEM-based mathematics teaching materials that refer to indicators of students' mathematical connection ability. Results of the n-gain average pretest and posttest are shown in table 5.

Table 5. The Result of N-gain Test

\begin{tabular}{cccc}
\hline \multicolumn{2}{c}{ Average } & N-Gain & Criteria \\
Pretest & Postest & & \\
\hline $\mathbf{2 4 , 4 6}$ & 71,9 & 0,628 & Medium \\
\hline
\end{tabular}

Result $n$-gain is 0.628 indicates that the increase occurred in the medium category (Hake, 1999). This shows that the use of STEM-based mathematics teaching materials can help improve mathematical connection ability. Based on Pangesti, Yulianti, \& Sugianto (2017), the similarity between this research with others is they all develop teaching materials and get results of n-gain in the medium category. Nevertheless, the difference with other research is improving the mathematical connection ability as a product of research results.

Indicators of mathematical connection ability are based on NCTM, namely connecting between topics in mathematics, in one mathematical topic, between mathematics with other sciences, and mathematics with daily life (Saminanto \& Kartono, 2015). Based on figure 2, the four indicators have experienced an increase in the average pretest and posttest value. The increase in mathematical connection ability using the n-gain test is shown in figure 3. 


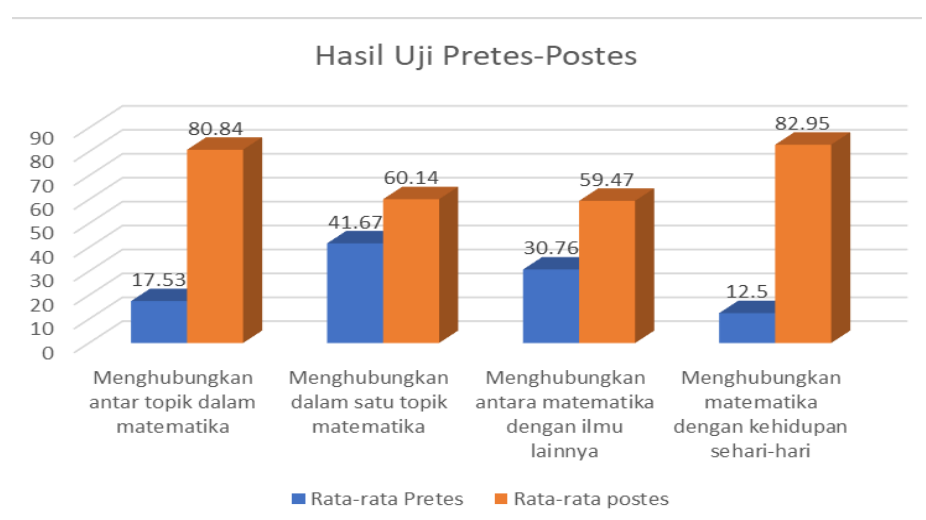

Figure 2. Result of Pretest - Posttest

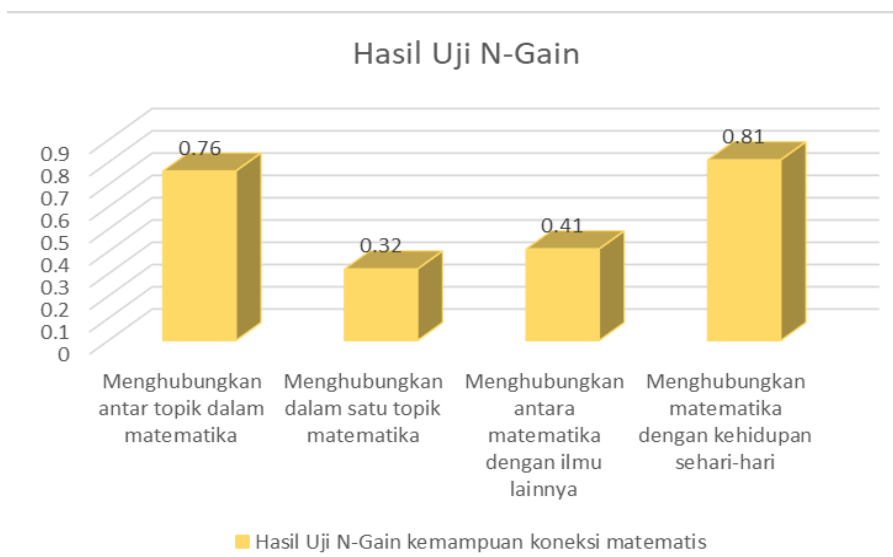

Figure 3. Result of n-gain Test

Results of N-gain test of each indicator that is connecting between topics in mathematics gained 0.76 in the high category, connecting in one mathematical topic gained 0.32 in the medium category, connecting mathematics with other sciences gained 0.41 in the medium category, and connecting mathematics with daily life gained 0.81 in the high category. Therefore, teaching material is concluded to be able to improve mathematical connection ability. STEM-based mathematics teaching materials that can improve mathematical connection ability and support research that teachers and book writers must prepare classroom learning that can improve the connection skills and the quality of problems associated with real-life in reading books (Altay, Yalvac, \& Yeltekin, 2017).

\section{Final Product}

The STEM-based mathematics teaching material is valid for learning, practicality score that is practical and easy to understand, and effective to 
increase mathematical connection ability, teaching material is put to be given ecopyrights. The final product of STEM-based mathematics teaching materials consists of three main components according to BSNP criteria, namely beginning, content, and closing of teaching material. Results of development teaching materials that refer to BSNP is declared to be valid and effectively used in the learning process (Arafah, Ridlo, \& Priyono, 2012). In this teaching material, each discussion of problems is solved with consistently in using mathematical connection indicators. Thus, the development of STEM-based mathematics teaching materials in the linear two-variable equation system can improve the mathematical connection ability.

From the result, mathematics teaching materials in this research can be used in learning, and the copyright was submitted by the electronic intellectual wealth General Directory. Based on (Rokhman \& Yuliati, 2010; Astuti, Hartono, Bunayati, \& Sriwijaya, 2017; Cloonan \& Fingeret, 2020), the similarity between this research with others is they all develop the teaching materials. Nevertheless, the differences with other research are the connection of teaching materials with STEM aspects that are valid, practical, and effective to increase mathematical connection ability as a product of research result.

\section{CONCLUSION}

STEM-based mathematics teaching material that was produced is valid to use in learning with an average percentage of validity $92.42 \%$. Teaching material containing the content validity aspect in criteria is excellent with a percentage of $93.36 \%$, the presentation validity aspects in criteria are excellent with a percentage of $93.82 \%$, and the language validity aspect in criteria is excellent with a percentage of $90.1 \%$. In addition, teaching material is practical and easily understood by students with a practical percentage of $87.56 \%$. These results indicate that students can answer the test questions with an average of 43 correct answers. Meanwhile, the result of the $n$-gain test is 0.628 on medium criteria showed an effective increase in students' mathematical connection ability. Thus, mathematics teaching materials in this research can be used in learning, and the copyright was submitted by the electronic intellectual wealth General Directory. However, the development of STEM mathematics teaching materials is still limited to the material of the two-variable linear equation system, so it is necessary to research the development of other materials. 


\section{REFERENCES}

Acar, D., Tertemiz, N., \& Tasdemir, A. (2018). The effects of STEM training on the academic achievement of 4 th graders in science and mathematics and their views on STEM training teachers. International Electronic Journal of Elementary Education, 10(4), 505-513. https://doi.org/10.26822/iejee. 2018438141.

Akbar, S. D. (2013). Instrumen perangkat pembelajaran. Bandung: PT Remaja Rosdakarya.

Altay, M. K., Yalvac, B., \& Yeltekin, E. (2017). 8th Grade student's skill of connecting mathematics to real life. Journal of Education and Training Studies, 5(10), 158. https://doi.org/10.11114/jets.v5i10.2614.s.

Arafah, S., Ridlo, S., \& Priyono, B. (2012). Pengembangan LKS berbasis berpikir kritis pada materi animalia. Journal of Biology Education, 1(1), 47-53. Retrieved from https://journal.unnes.ac.id/sju/index.php/ujbe/article /view/378.

Arikan, A. (2014). An examination of online grammar teaching materials available for young learners. Procedia - Social and Behavioral Sciences, 158, 18-22. https:// doi.org/10.1016/j.sbspro.2014.12.026.

Astuti, P., Hartono, Y., Bunayati, H., \& Sriwijaya, U. (2017). Pengembangan LKS berbasis pendekatan pemodelan matematika untuk melatih kemampuan koneksi matematis siswa SMP kelas VIII. Jurnal Pendidikan Matematika, 11(2), 61-77. https:/ / doi.org/10.22342/jpm.11.2.4613.61-78.

Badjeber, R., \& Fatimah, S. (2015). Peningkatan kemampuan koneksi matematis siswa SMP melalui pembelajaran inkuiri model alberta. Jurnal Pengajaran Matematika dan Ilmu Pengetahuan Alam, 20(1), 18. https://doi.org/ 10.18269/jpmipa.v20i1.557.

BSNP. (2015). Pedoman penilaian buku teks matematika. Jakarta: Ristekdikti.

Chiou, C.-C., Lee, L.-T., \& Liu, Y.-Q. (2012). Effect of novak colorful concept map with digital teaching materials on student academic achievement. Procedia - Social and Behavioral Sciences, 64, 192-201. https://doi.org/ 10.1016/j. sbspro.2012.11.023.

Cloonan, M., \& Fingeret, A. L. (2020). Developing teaching materials for learners in Surgery. Surgery (United States), 167(4), 689-692. https://doi.org/ 10.1016/j.surg.2019.05.056.

Depdiknas. (2003). UU Nomor 20 Tahun 2003 tentang Sistem Pendidikan Nasional. Jakarta: Depdiknas.

Dobres, J., Chahine, N., \& Reimer, B. (2017). Effects of ambient illumination, contrast polarity, and letter size on text legibility under glance-like reading. Applied Ergonomics, 60, 68-73. https:/ / doi.org/10.1016/j.apergo. 2016. 11.001.

Hake, R. R. (1999). Analyzing change/gain scores. Dept. of Physics Indiana University. Unpublished. [Online]. http://www.Physics.Indiana. Edu/ 
Sdi/ AnalyzingChange-Gain. pdf.

John, M., Bettye, S., Ezra, T., \& Robert, W. (2016). A formative evaluation of a Southeast High School Integrative science, technology, engineering, and mathematics (STEM) academy. Technology in Society, 45, 34-39. https://doi.org/10.1016/j.techsoc.2016.02.001.

Kemendikbud. (2018). Penyegaran Infrastruktur Kurikulum 2013. Jakarta: Kemendikbud.

Kolomuc, A., Ozmen, H., Metin, M., \& Acisli, S. (2012). The effect of animation enhanced worksheets prepared based on 5E model for the grade 9 students on alternative conceptions of Physical and Chemical Changes. Procedia-Social and Behavioral Sciences, 46, 1761-1765. https://doi.org/ 10.1016/ j.sbspro.2012.05.374.

Lou, S. J., Shih, R. C., Diez, C. R., \& Tseng, K. H. (2011). The impact of problembased learning strategies on STEM knowledge integration and attitudes: An exploratory study among female Taiwanese senior high school students. International Journal of Technology and Design Education, 21(2), 195-215. https://doi.org/10.1007/s10798-010-9114-8.

National Council of Teacher of Mathematics (NCTM). (2000). Principles and standards for school mathematics. Reston: The National Council of Teachers of Mathematics, Inc.

Nugraha, D. A., \& Binadja, A. (2013). Pengembangan bahan ajar reaksi redoks bervisi sets, berorientasi konstruktivistik. Journal of Innovative Science Education, 2(1), 27-34. Retrieved from https://journal.unnes.ac.id/sju/ index.php/jise/article/view/1289.

Nurichah, E. (2012). Pengembangan Lembar kegiatan siswa berbasis keterampilan berpikir kritis pada materi keanekaragaman hayati. BioEdu, 1(2), 45-49. Retrieved from https://jurnalmahasiswa.unesa.ac.id/index. $\mathrm{php} /$ bioedu/article/view/487.

Pangesti, K. I, Yulianti, D., \& Sugianto. (2017). Bahan ajar berbasis STEM (Science, Technology, Engineering, and Mathematics) untuk meningkatkan penguasaan konsep siswa SMA. Unnes Physics Education Journal, 6(3), 53-58. https://doi.org/10.1089/ars.2015.6320.

Phungsuk, R., Viriyavejakul, C., \& Ratanaolarn, T. (2017). Development of a problem-based learning model via a virtual learning environment. Kasetsart Journal of Social Sciences, 38(3), 297-306. https://doi.org/ 10.1016/j.kjss. 2017.01.001.

Pimthong, P., \& Williams, J. (2020). Preservice teachers' understanding of STEM education. Kasetsart Journal of Social Sciences, 41(2), 289-295. https:// doi.org/10.1016/j.kjss.2018.07.017.

Pujiastuti, E., Mulyono, \& Soedjoko, E. (2018). Pengungkapan koneksi matematis sebagai sarana penelusuran kemampuan dan proses memecahkan masalah peserta didik. PRISMA, Prosiding Seminar Nasional 
Matematika, 1, 618-627. Retrieved from https://journal.unnes.ac.id/sju/ index.php/prisma/ article/view/20207.

Rohendi, D., \& Dulpaja, J. (2013). Connected Mathematics Project (CMP) model based on presentation media to the mathematical connection ability of Junior High School Student. Journal of Education and Practice 4(4), 17-22. Retrieved from https://www.iiste.org/Journals/index.php/JEP/article /view/4512.

Rokhman, F., \& Yuliati. (2010). The development of the Indonesian teaching material based on multicural context by using sociolinguistic approach at junior high school. Procedia - Social and Behavioral Sciences, 9, 1481-1488. https://doi.org/10.1016/j.sbspro.2010.12.353.

Rosmaini. (2009). Keterbacaan buku teks. Medan: FBS UNIMED.

Saminanto \& Kartono. (2015). Analysis of mathematical connection ability in linear equation with one variable based on connectivity theory. International Journal of Education and Research, 3(4), 259-270. Retrieved from https:// www.ijern.com/journal/2015/April-2015/22.pdf.

Sanders, M., E. (2009). STEM, STEMEducation, STEMmania. The Technology Teacher, 68(4), 20-27. Retrieved from http://hdl.handle.net/10919/ 51616.

Setiawan, F. T., Suyitno, H., \& Susilo, B. E. (2017). Analysis of mathematical connection ability and mathematical disposition students of 11th grade Vocational High School. Unnes Journal of Mathematics Education, 6(2), 152162. https://doi.org/10.15294/ujme.v6i2.13135.

Sudijono. (2014). Pengantar statistik pendidikan. Jakarta: Grafindo Persada.

Sugiyono. (2017). Metode penelitian pendidikan. Bandung: Alfabeta.

Tsai, H. C., Jou, M., Wang, J. Y., \& Huang, C. C. (2017). An empirical study on the incorporation of APP and progressive reasoning teaching materials for improving technical creativity amongst students in the subject of automatic control. Computers in Human Behavior, 75, 997-1007. https://doi.org/10.1016/j.chb.2016.10.031.

Tseng, K. H., Chang, C. C., Lou, S. J., \& Chen, W. P. (2013). Attitudes towards Science, Technology, Engineering And Mathematics (STEM) in a ProjectBased Learning (PjBL) environment. International Journal of Technology and Design Education, 23(1), 87-102. https://doi.org/10.1007/s10798-0119160x.

Utami, T. N., Jatmiko, A., \& Suherman, S. (2018). Pengembangan Modul Matematika dengan Pendekatan Science, Technology, Engineering, And Mathematics (STEM) pada Materi Segiempat. Desimal: Jurnal Matematika, 1(2), 165. https://doi.org/10.24042/djm.v1i2.2388. 